\title{
MACROZOOBENTHOS OF THE ZERNOV'S PHYLLOPHORA FIELD, NORTHWESTERN BLACK SEA: SPECIES RICHNESS, QUANTITATIVE REPRESENTATION AND LONG-TERM VARIATIONS
}

\author{
Nikolay K. Revkov*, Natalya A. Boltacheva, Vitaliy A. Timofeev, \\ Igor P. Bondarev, Lyudmila V. Bondarenko
}

A.O. Kovalevsky Institute of Marine Biological Research of RAS, Russia e-mail:*nrevkov@yandex.ru,n.boltachova.15@gmail.com,tamplier74@mail.ru, igor.p.bondarev@gmail.com,bondarenko.luda@gmail.com

Received: 28.03.2018

\begin{abstract}
The Zernov's Phyllophora Field (ZPF) is a water area in the northwestern Black Sea (NWBS) that occupied about $11000 \mathrm{~km}^{2}$ in the early $20^{\text {th }}$ century. Since 2008, a water area of $4025 \mathrm{~km}^{2}$ has been given the status of a botanical sanctuary of national importance «Zernov's Phyllophora Field». The goal of the present study is to assess the species richness and quantitative development of macrozoobenthos of the ZPF and their long-term variations under the current conditions of de-eutrophication of the Black Sea basin. The work is based on the material of 43 benthos stations performed in 2010-2013 within an area of $8400 \mathrm{~km}^{2}$ in the ZPF. In 2010-2013, a total of 162 macrozoobenthos species were identified: Polychaeta (49 species), Mollusca (39), Crustacea (43), Ascidiacea (6); the other taxa comprised 25 species. The current level of species richness of macrozoobenthos is the highest for the entire historical period of the ZPF studies. The mean abundance and wet biomass of macrozoobenthos were estimated at $2417 \pm 175$ individuals $/ \mathrm{m}^{2}$ and $283 \pm 32 \mathrm{~g} / \mathrm{m}^{2}$ (without mantle cavity fluid of bivalves). Values for Polychaeta amounted to 1017 individuals $/ \mathrm{m}^{2}$ and $6 \mathrm{~g} / \mathrm{m}^{2}$, Mollusca -887 individuals $/ \mathrm{m}^{2}$ and $256 \mathrm{~g} / \mathrm{m}^{2}$, Crustacea -165 individuals $/ \mathrm{m}^{2}$ and $1.3 \mathrm{~g} / \mathrm{m}^{2}$, Ascidiacea -42 individuals $/ \mathrm{m}^{2}$ and $17 \mathrm{~g} / \mathrm{m}^{2}$. The biomass of the dominant species, the filter-feeders Mytilus galloprovincialis, reaches $73 \%$ of the total macrozoobrnthos biomass. Our research of the long-term alterations in benthic macrofauna covers the period 1957 to 2013, including the pre-crisis time of the Black Sea ecosystem (1957-1960), its crises of the second half of the $20^{\text {th }}$ century $(1979,1984,1991)$ and the modern (post-crisis) stage $(2010-2013)$. Based on the maps of biomass spatial distribution for all periods mentioned above, the mean values and the total stocks of macrozoobenthos within the area $8400 \mathrm{~km}^{2}$ of the ZPF were evaluated. The long-term changes of the macrozoobenthos biomass were analysed in relation to the main factors adversely affected the bottom biocoenoses in NWBS - i.e. anthropogenic eutrophication, oxygen depletion and near-bottom hypoxia in summer, as well as the secondary siltation of the seabed due to intensive near-bottom trawling. The most critical period for the ZPF ecosystem state occurred in the late 1970s, when the mean biomass and the total stock of macrozoobenthos decreased by 7 times in comparison with the pre-crisis period. The data collected in the first decades of the $21^{\text {st }}$ century indicate the actual recovery of the mean macrozoobenthos biomass and of its total stock in the ZPF area to the level of 1957-1960, which is related to the improving of the general ecological situation in the region.
\end{abstract}

Key words: abundance, benthic macrofauna, biomass, long-term dynamics, Marine Protected Area, Phyllophora, stocks of macrozoobenthos

\section{Introduction}

The Zernov's Phyllophora Field (ZPF) is the area in the northwestern Black Sea (NWBS) shelf occupying about $11000 \mathrm{~km}^{2}$ (Zaitsev, 2006) on the sloping accumulative plain with depths of 20-60 m (Fig. 1). Its bottom is covered with fields of shell debris including various pelitic components (Emelianov et al., 2004). The academician Zernov $(1909,1913)$ discovered it in the early $20^{\text {th }}$ century and its name is related to the previously huge aggregation of agariferous red algae of the genus Phyllophora. According to various estimates, the total stocks of phyllophora in that period amounted from 5 to 10 million tons (Zenkevich, 1956; Zaitsev \& Mamaev, 1997). Due to the tremendous stocks of alga Phyllophora, located here until the 1980s, it was called the «lungs» of the basin, and harvesting of Phyllophora was of great importance for the economy of the former USSR.

Since 2008, the ZPF has been included as a botanical reserve in the marine protected areas (MPAs) of the Black Sea (Nature reserves fund of Ukraine, 2009). For today, the ZPF is the largest MPA, occupying an area of $4025 \mathrm{~km}^{2}, 51 \%$ of the area of all 54 MPAs legally established in the Black Sea basin (Milchakova, 2011, 2016). According to the European Red List of Habitats, the central part of the NWBS in the area of the ZPF location is presently classified as «Pontic circalittoral biogenic detritic bottoms with dead or alive mussel beds, shell deposits, with encrusting corallines 
(Phymatolithon, Lithothamnion) and attached foliose sciaphilic macroalgae» and is referred to Critically Endangered habitats (Gubbay et al., 2016).

The studies on zoobenthos in the ZPF started in the early $20^{\text {th }}$ century as a description of the taxonomic composition of the fauna inhabiting the Phyllophora bed (Zernov, 1913). The first quantitative data on the benthic fauna in the Phyllophora field were collected in 1957-1960 during an extensive benthic survey: the grid of 228 stations covered an area of $40000 \mathrm{~km}^{2}$ in almost the entire NWBS shelf. The various aspects of the biology and ecology of the communities in NWBS as well as the results of analysis of the species composition and quantitative indices of zoobenthos in the ZPF in that time were generalised in a special monograph (Vinogradov \& Zakutsky, 1967). The subsequent similar data on quantitative representation and taxonomical diversity of macrozoobenthos in the ZPF, obtained during 1970-2002, were summarised by Losovskaya (2006) and Sinegub (2006). In that period, in addition to traditional sampling gears such as grab, the observations of the bottom surface were conducted from submersible remote sensing vehicles of the TINRO-2 and BENTOS-300 types (Samyshev et al., 1986; Zolotarev, 1994). The data of recent decades are represented by the results of three main benthic surveys performed in the area of the ZPF in 1991 (Mikhailova, 2002), 2012 (Kovalishina \& Kachalov, 2015), and 2010-2013 (own data).

The goal of this study is to clarify the species richness and quantitative representations of macrozoobenthos at the Zernov's Phyllophora Field in the present period under conditions of de-eutrophication of the Black Sea basin. An important component of the work was a retrospective analysis of mapped material in order to evaluate the long-term changes of macrozoobenthos throughout the sea bottom area of $8400 \mathrm{~km}^{2}$ located within the zone of the ZPF.

\section{Material and Methods}

The work was based on the results of benthic surveys conducted in the waters of the ZPF during the cruises \#68 (2010), \#70 (2011) and \#72 (2013) aboard research vessel «Professor Vodyanitsky». All quantitative material was collected by an «Ocean-50» grab sampler (with area of $0.25 \mathrm{~m}^{2}$ ) at 43 stations within a depth range of 19-60 m (Fig. 1). At each station, 1-2 samples were taken. They were washed through a system of sieves with mesh size of $3 \mathrm{~mm}$ and $1 \mathrm{~mm}$. At one station material was also collected by a Sigsbee-Agassiz trawl and by a scuba-diver at two other stations.

Prior to washing, a sample with sediment was divided into portions and placed in plastic baths, where «fragile» benthic organisms (polychaetes, crustaceans, ascidians, etc.) were collected using a gentle technique of stirring (flotation method) and pouring the sample out on a sieve, thus, avoiding the stage of their direct washing together with coarse sediment fractions (sand and shell debris). Animals from the upper sieve of $3 \mathrm{~mm}$ mesh size, were fixed immediately after washing in $4 \%$ neutralised formaldegide (for polychaetes) or for other taxa - in $76 \%$ alcohol. A portion of the washed sample (with a volume of up to $300 \mathrm{ml}$ ) from both the upper and lower sieves was fixed in a $4 \%$ neutralised formalin solution for the subsequent microscopy at a shore-based laboratory. The volume of sediment that remained on the washing sieves was measured with a measuring glass $(\mathrm{V}=300 \mathrm{ml})$ in order to determine the aliquot taken for analysis and to express the results of quantitative assessment of benthic fauna per $1 \mathrm{~m}^{2}$ of the bottom area.
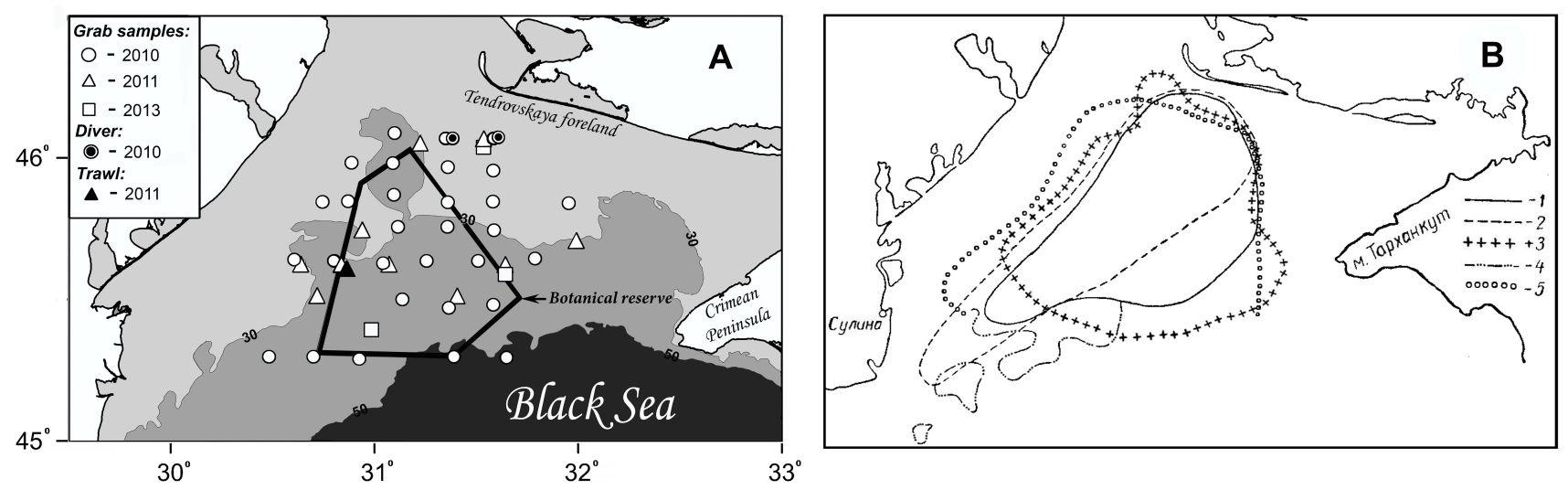

Fig. 1. A: Arrangement of benthic stations performed during the expeditions aboard research vessel «Professor Vodyanitsky» in the area of Zernov's Phyllophora Field. B: Boundaries of Zernov's Phyllophora Field, depicted in the work of Vinogradov \& Zakutsky (1967) according to the data of different authors: (1) Zernov (1909, 1913); (2) Berenbeim (1953); (3) Shchapova (1954); (4) Skolka (1956); (5) Vinogradov (1957). 
Species synonymy was checked using the WoRMS (WoRMS Editorial Board, 2018) database. Such taxa as Oligochaeta, Nemertea, Platyhelminthes, Gromia, Porifera, and Hydrozoa were not identified to the species level. Biomass of bivalves was estimated after cutting the adductor muscles and removing the mantle cavity fluid by drying on filter paper for a short time. All animals were weighed on a SARTORIUS digital scale balance with an accuracy of $0.001 \mathrm{~g}$.

The zone of the ZPF including our sampling stations in 2010-2013 (Fig. 1A) covers an area of 8400 $\mathrm{km}^{2}$. The data collected from this area were used for analysis of long-term changes in macrozoobenthos biomass. For these purposes, the maps of spatial distribution of macrozoobenthos biomass in 1957-1960 (Nikitin, 1964), in 1979, 1984 (Samyshev et al., 1986) and 1991 (Mikhailova, 2002) within the selected area were considered. The data for 1991 provided by Mikhailova (2002), as well as our own data were plotted on maps using SURFER 13 mapping software. The areas occupied by a certain biomass of zoobenthos were estimated for all maps using this software, too. The total stocks of macrozoobenthos and average values of the taxa biomass within the $8400 \mathrm{~km}^{2}$ area of the ZPF have been calculated with the STATISTICA 6 software package.

As known from the early studies, the total biomass of bivalves, which form a major part of zoobenthos biomass, was assessed without removing their mantle cavity fluid. In order to compare correctly the results obtained from the long-term data series, in the material of 2010-2013 we assessed the wet biomass of bivalve mollusks with mantle cavity fluid and without mantle cavity fluid; the coefficients of relationship were determined. According to our data, mantle cavity fluid of Bivalvia in alcohol-fixed samples accounts from $19 \%$ to $52 \%$ of the mollusks weight. The greatest variations in weight due to the loss of mantle cavity fluid might be in the thin-shelled mollusks Abra nitida (O.F. Müller, 1776), Gibbomodiola adriatica (Lamarck, 1819), Modiolula phaseolina (Philippi, 1844), Abra alba (W. Wood, 1802), and Acanthocardia paucicostata (G.B. Sowerby II, 1834) (Table 1). In the large-sized Mytilus galloprovincialis Lamarck, 1819 such losses may constitute up to $40 \%$ of their initial «alive» weight.

Table 1. Table of coefficients of relationship (K) between the wet biomass of mollusks without mantle cavity fluid and that of mollusks with mantle cavity fluid

\begin{tabular}{|c|c|c|c|}
\hline Taxon & Number of measurements & $\begin{array}{l}\text { Range of lengths, } \\
\mathrm{mm}\end{array}$ & $\mathrm{K}$ \\
\hline Abra alba (W. Wood, 1802) & 13 & $2.2-8.4$ & 1.75 \\
\hline Abra nitida (O.F. Müller, 1776) & 5 & $3.1-4.5$ & 2.15 \\
\hline Acanthocardia paucicostata (G.B. Sowerby II, 1834) & 2 & $2.7 ; 5.8$ & 1.74 \\
\hline Anadara kagoshimensis (Tokunaga, 1906) & 30 & $1.5-44.0$ & 1.36 \\
\hline Chamelea gallina (Linnaeus, 1758) & 65 & $8.5-21.3$ & 1.29 \\
\hline Gastrana fragilis (Linnaeus, 1758) & 1 & 9.3 & 1.74 \\
\hline Gibbomodiola adriatica (Lamarck, 1819) & 4 & $18-30.6$ & 2.01 \\
\hline Gouldia minima (Montagu, 1803) & 67 & $3.5-10.4$ & 1.22 \\
\hline Lucinella divaricata (Linnaeus, 1758) & 3 & $2.4-4.8$ & 1.31 \\
\hline Modiolula phaseolina (Philippi, 1844) & 77 & $2.6-12.4$ & 1.86 \\
\hline Mytilaster lineatus (Gmelin, 1791) & 149 & $3.3-16.5$ & 1.41 \\
\hline Mytilus galloprovincialis Lamarck, 1819 & 137 & $11.5-72.0$ & 1.67 \\
\hline Papillicardium papillosum (Poli, 1791) & 57 & $4.4-11.4$ & 1.37 \\
\hline Parvicardium exiguum (Gmelin, 1791) & 56 & $6.5-11.8$ & 1.33 \\
\hline Pitar rudis (Poli, 1795) & 131 & $2.5-17.3$ & 1.44 \\
\hline Polititapes aureus (Gmelin, 1791) & 10 & $15.6-29.7$ & 1.44 \\
\hline Spisula subtruncata (da Costa, 1778) & 15 & $7.4-17.0$ & 1.38 \\
\hline $\begin{array}{l}\text { Tellinidae spp. (Fabulina fabula (Gmelin, 1791), Maco- } \\
\text { mangulus tenuis (da Costa, 1778)) }\end{array}$ & 2 & $10.3 ; 11.9$ & 1.35 \\
\hline
\end{tabular}




\section{Results}

Species richness. A total of 162 species of benthic macrofauna were found in the study area. The total species list is available in the article of Revkov et al. (2016). Polychaetes were represented by 49 species; mollusks, by 39 species, including 19 species of Bivalvia, 19 Gastropoda and 1 species of Polyplacophora, crustaceans - by 43 species, ascidians - by 6 species, and other taxa were represented by 25 species. The most frequently occurring species (found at $25 \%$ of the stations or more) in the area of the ZPF were represented by 8 polychaetes, 2 crustaceans, 4 bivalves, and by one species of bryozoans and ascidians each (Table 2).

The polychaete Polycirrus jubatus Bobretzky, 1868 and two crustacean Gammarellus carinatus (Rathke, 1843) and Apseudopsis ostroumovi Bacescu \& Carausu, 1947, are endemic species of the Black Sea. Five species are known as invasive that have appeared in the Black Sea recently. These are the mollusks Mya arenaria Linnaeus, 1758, Anadara kagoshimensis (Tokunaga, 1906), Rapana venosa (Valenciennes, 1846), and the polychaetes Dipolydora quadrilobata (Jacobi, 1883) and Polydora cornuta Bosc, 1802.

Among the benthic high-level taxa, the richest were the order Phyllodocida, phylum Annelida (28 species), the order Amphipoda, phylum Arthropoda (23 species) and the order Heterodonta, phylum Mollusca (15 species).
Ten high-level taxa are represented only by single species: order Eunicida (phylum Annelida) by Protodorvillea kefersteini (McIntosh, 1869)); orders Tanaidacea and Sessilia (Arthropoda) by Apseudopsis ostroumovi and Amphibalanus improvisus (Darwin, 1854) accordingly; the families Phasianellidae, Littorinimorpha and Caenogastropoda (Mollusca: Gastropoda) by Tricolia pullus (Linnaeus, 1758), Vitreolina incurva (Bucquoy, Dautzenberg \& Dollfus, 1883) and Epitonium clathrus (Linnaeus, 1758) accordingly; the family Chitonida (Mollusca: Polyplacophora) by Lepidochitona cinerea (Linnaeus, 1767); the family Phoronidae (Phoronida) by Phoronis psammophila Cori, 1889; the family Aplousobranchia (Chordata: Ascidiacea) by Diplosoma listerianum (Milne Edwards, 1841) and the family Ophiurida (Echinodermata) by Amphiura stepanovi Djakonov, 1954. All mentioned species above have to be considered as species with a high rank of taxonomic exclusiveness, on the taxonomic tree of benthic community they form separate (monospecific) branches closing up on a high hierarchical level (Warwick \& Clarke, 2001; Nevrova et al., 2015). Elimination of each of them leads to extinction of the entire family or even order arms from the taxonomic structure, which can substantially decrease the total taxonomic diversity of macrozoobenthos.

Table 2. Quantitative characteristics of the most frequent species at the Zernov's Phyllophora Field area

\begin{tabular}{|c|c|c|c|}
\hline \multirow[b]{2}{*}{ Taxon } & \multirow[b]{2}{*}{ Frequency, $\%$} & \multicolumn{2}{|c|}{ Average values of } \\
\hline & & $\begin{array}{c}\text { abundance, } \\
\text { individuals } / \mathrm{m}^{2}\end{array}$ & biomass, $\mathrm{g} / \mathrm{m}^{2}$ \\
\hline Mytilus galloprovincialis Lamarck, 1819 & 43 & $427 \pm 57(1352)$ & $205.466 \pm 28.189(983.63)$ \\
\hline Prionospio cirrifera Wirén, 1883 & 41 & $444 \pm 84(2204)$ & $0.422 \pm 0.095(3.300)$ \\
\hline Heteromastus filiformis (Claparède, 1864) & 40 & $77 \pm 17(558)$ & $0.141 \pm 0.030(0.981)$ \\
\hline Nemertea & 40 & $33 \pm 5(152)$ & $0.137 \pm 0.019(0.518)$ \\
\hline Cryptosula pallasiana (Moll, 1803) & 36 & $52 \pm 20(808)$ & $0.543 \pm 0.214(8.570)$ \\
\hline Nephtys hombergii Savigny in Lamarck, 1818 & 34 & $22 \pm 5(178)$ & $1.215 \pm 0.240(7.088)$ \\
\hline Phtisica marina Slabber, 1769 & 32 & $30 \pm 6(164)$ & $0.017 \pm 0.004(0.097)$ \\
\hline Ascidiella aspersa (Müller, 1776) & 32 & $17 \pm 4(96)$ & $10.042 \pm 2.225(77.520)$ \\
\hline Parvicardium exiguum (Gmelin, 1791 & 30 & $23 \pm 6(212)$ & $1.142 \pm 0.325(10.260)$ \\
\hline Dipolydora quadrilobata (Jacobi, 1883) & 29 & $147 \pm 44(1197)$ & $0.288 \pm 0.085(2.232)$ \\
\hline Papillicardium papillosum (Poli, 1791) & 29 & $17 \pm 4(164)$ & $1.090 \pm 0.282(9.483)$ \\
\hline Pholoe inornata Johnston, 1839 & 28 & $41 \pm 12(460)$ & $0.031 \pm 0.009(0.360)$ \\
\hline Modiolula phaseolina (Philippi, 1844) & 28 & $278 \pm 80(2048)$ & $13.970 \pm 3.725(85.736)$ \\
\hline Spirobranchus triqueter (Linnaeus, 1758) & 27 & $12 \pm 3(76)$ & $0.059 \pm 0.016(0.600)$ \\
\hline Harmothoe reticulata (Claparède, 1870) & 26 & $14 \pm 4(126)$ & $0.077 \pm 0.019(0.480)$ \\
\hline Terebellides stroemii Sars, 1835 & 25 & $18 \pm 4(126)$ & $1.388 \pm 0.420(14.324)$ \\
\hline Amphibalanus improvisus (Darwin, 1854) & 25 & $17 \pm 5(150)$ & $0.515 \pm 0.141(3.677)$ \\
\hline
\end{tabular}

Note: Average values and their standard errors are given, maximum values are given in brackets. The abundance of Cryptosula pallasiana was calculated for colonies per $1 \mathrm{~m}^{2}, 1$ colony $=100$ zooids. 
Another group of 45 species are rare and were recorded only from one of the 43 stations. Among them the gastropods Tricolia pullus, Vitreolina incurva, Epitonium clathrus, and the colonial ascidian Diplosoma listerianum.

A total of five species present within the ZPF have a protected status in various water areas of the Black Sea basin. Among crustaceans, these are $A p$ seudopsis ostroumovi, Diogenes pugilator (Roux, 1829), Upogebia pusilla (Petagna, 1792), and Liocarcinus navigator (Herbst, 1794); among mollusks, Gastrana fragilis (Linnaeus, 1758) (Dumont et al., 1999; Akimov, 2009; Ivanov \& Fateryga, 2015).

Quantitative characteristics. The average ( \pm $\mathrm{SE)}$ abundance of macrozoobenthos is $2417 \pm 175$ individuals $/ \mathrm{m}^{2}$, with the highest density of polychaetes $(1017 \pm 128)$ and mollusks $(887 \pm 102)$. Crustaceans show a value of $165 \pm 20$; ascidians, $42 \pm 9$; the combined group of the other taxa, $301 \pm$ 51 individuals $/ \mathrm{m}^{2}$. The polychaetes Prionospio cirrifera Wirén, 1883, Dipolydora quadrilobata, and the mollusks Mytilus galloprovincialis and Modiolula phaseolina, are the most abundant and refer also to the group of the most frequently occurring species in the ZPF area (Table 2).

The lowest values of the total macrozoobenthos abundance were recorded in the northern part of the ZPF, at depths exceeding $30 \mathrm{~m}$. The areas with a low abundance of mussels, polychaetes, and crustaceans were larger at the same isobaths and expanded from north to south in the form of a narrow belt (Fig. 2). The recent invasive species $\mathrm{Di}$ polydora quadrilobata was the most abundant in the southwestern part.

The average biomass of macrozoobenthos reaches $283.4 \pm 32.3 \mathrm{~g} / \mathrm{m}^{2}$, with the highest values of mollusks $\left(256.3 \pm 30.0 \mathrm{~g} / \mathrm{m}^{2}\right)$, followed by ascidians $\left(17.1 \pm 3.5 \mathrm{~g} / \mathrm{m}^{2}\right)$, polychaetes $\left(6.4 \pm 0.8 \mathrm{~g} / \mathrm{m}^{2}\right)$ and crustaceans $\left(1.3 \pm 0.3 \mathrm{~g} / \mathrm{m}^{2}\right)$. The filter-feeders were the dominant group of benthos in terms of biomass.

Along with the above-mentioned bivalves from the group of the most common species, such as Mytilus galloprovincialis, Modiolula phaseolina and the ascidians Ascidiella aspersa (Müller, 1776) (Table 2), the highest biomass in the ZPF area also reach the bivalves Mytilaster lineatus (Gmelin, 1791) $\left(15.2 \pm 7.9 \mathrm{~g} / \mathrm{m}^{2}\right)$, Chamelea gallina (Linnaeus, 1758$)\left(8.7 \pm 7.7 \mathrm{~g} / \mathrm{m}^{2}\right)$ and the ascidians Ciona intestinalis (Linnaeus, 1767) $\left(6.5 \pm 2.1 \mathrm{~g} / \mathrm{m}^{2}\right)$.

The spatial pattern of biomass values is determined mainly by the distribution of mollusks, among which the biomass of mussels constitutes an average of $73 \%$ of the total biomass of macrozoobenthos over the area (Fig. 3). The highest biomass of Modiolula phaseolina was recorded from the southern and southeastern parts of the area.
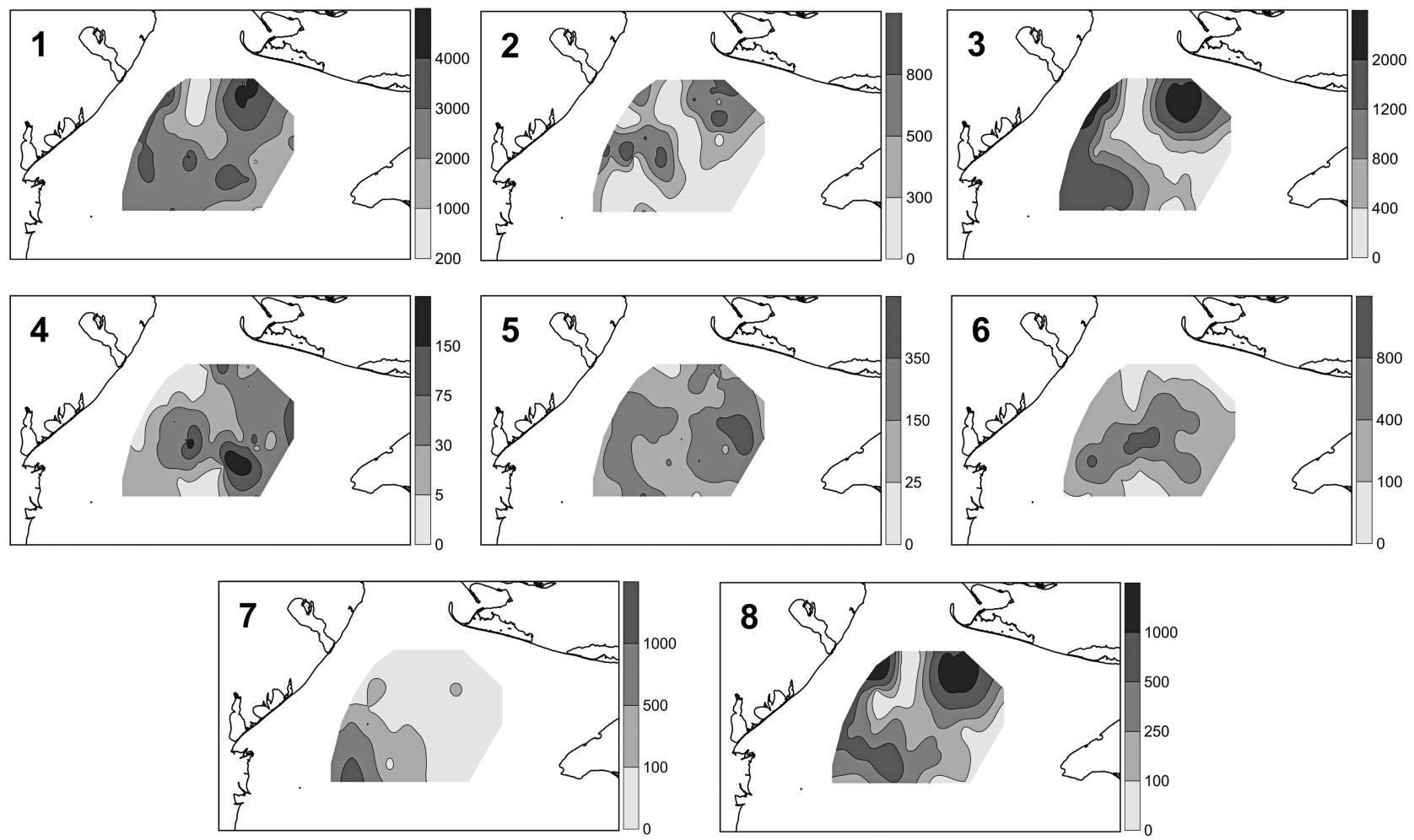

Fig. 2. Pattern of the abundance values (individuals $/ \mathrm{m}^{2}$ ) of various macrozoobenthos taxa in the area of Zernov's Phyllophora Field: (1) total abundance of macrozoobenthos; (2) Mytilus galloprovincialis; (3) Polychaeta; (4) Ascidiacea; (5) Crustacea; (6) Myscellaneous; (7) Dipolydora quadrilobata; (8) Prionospio cirrifera. 

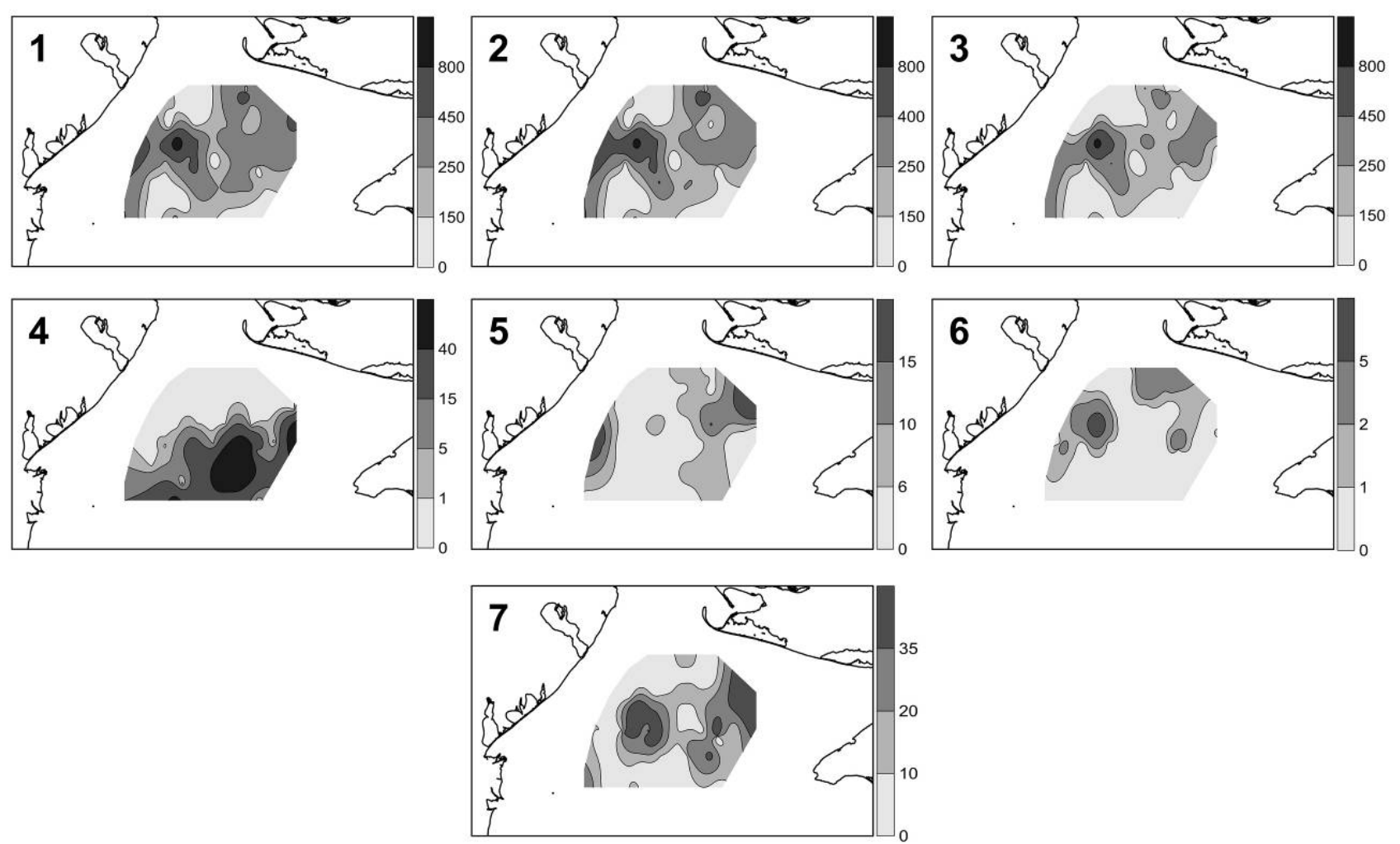

Fig. 3. Pattern of the biomass values $\left(\mathrm{g} / \mathrm{m}^{2}\right)$ of various macrozoobenthos taxa in the area of Zernov's Phyllophora Field: total biomass of macrozoobenthos (1), Mollusca (2), Mytilus galloprovincialis (3), Modiolula phaseolina (4), Polychaeta (5), Crustacea (6), Ascidiacea (7).

\section{Discussion \\ Species richness and its long-term variations.} The list of macrozoobenthos species recorded in the ZPF area in the early $20^{\text {th }}$ century includes 28 taxa (Zernov, 1913). These are crustaceans, Liocarcinus navigator, Idotea sp. and Crangon sp.; amphiurans Amphiura stepanovi, Synapta sp.; various sponges; ascidians Ciona sp.; polychaetes Polynoe g. sp., Terebellidae g. sp., Nereididae g. sp.; mollusks Parvicardium simile (Milaschewitsch, 1909), P. exiguum, Mytilus galloprovincialis, Modiolula phaseolina, Mytilaster lineatus, Abra alba, Kurtiella bidentata (Montagu, 1803)), Calyptraea chinensis (Linnaeus, 1758), Rissoa splendida Eichwald, 1830, R. euxinica Milaschevich, 1909, Bittium reticulatum (da Costa, 1778), B. submammillatum (de Rayneval \& Ponzi, 1854), Cerithiopsis tubercularis (Montagu, 1803), Monophorus perversus (Linnaeus, 1758)), Trophonopsis breviata (Jeffreys, 1882), Retusa variabilis (Milaschewitsch, 1912), and R. truncatula (Bruguière, 1792). Obviously, this relatively scarce fauna composition can be a result of the sporadic (or not detailed) studies in the area, as well as the inconsistency of the taxonomic system in those days.

The species richness of the benthic macrofauna of the ZPF estimated in 2010-2013, increases significantly in comparison to previously published data (Table 3). Such disagreement cannot be explained by the difference in number of performed benthic stations: 43 (2010-2013) versus 27 (1991), 50 (2012), 57 (1957-1960), but, probably, by a discrepancy in sampling and treatment of samples procedures (for instance, in 1991 the samples were washed only through the $2 \mathrm{~mm}$ mesh (Mikhailova, 2002)) and incomplete taxonomic identifications.

The species richness of the benthic macrofauna of the ZPF area is comparable to that in other water areas of the NWBS (Table 4). The total number of species in the Danube - Dniester coastal region, Karkinitskiy Gulf and Central (ZPF) area of the NWBS shelf displayed similar values. A comparison of species number of the main macrozoobenthos groups has shown a similarity between the ZPF and the Karkinitskiy Gulf area. The most freshened waters of the Danube - Dniester and Dnieper - Bug coastal areas are characterised by predominance of crustaceans due to the development of amphipods.

Long-term dynamics of biomass and stocks of macrozoobenthos. According to the map representing the results of the first quantitative studies of NWBS shelf in 1957-1960 (Zakutsky, 1962a), the zoobenthos biomass in a major part of the ZPF area varies from $500-600 \mathrm{~g} / \mathrm{m}^{2}$ to $1000-2000 \mathrm{~g} / \mathrm{m}^{2}$ (Fig. 4). Besides, in the same paper is mentioned that the 
mean zoobenthos biomass in the ZPF is $458 \mathrm{~g} / \mathrm{m}^{2}$. The discrepancy in the presented graphical and table data is evident. Our calculations using the map data show that the value of mean biomass within the area of the ZPF (Fig. 4) exceeded $700 \mathrm{~g} / \mathrm{m}^{2}$, which is 1.5 times higher than reported by the author. Subsequent- ly the author of the material confirmed the validity of the table data and used them in his later works (Zakutsky, 1962b; Vinogradov \& Zakutsky, 1967). Nevertheless, only the graphical material presented in Zakutsky (1962a) was used in later publications of some other authors (Nikitin, 1964; Samyshev et al., 1986).

Table 3. Species richness of benthic macrofauna in the Zernov's Phyllophora Field area in different years

\begin{tabular}{|c|c|c|c|c|c|c|}
\hline Years & Total number of species & Mollusca & Polychaeta & Crustacea & Other & Reference \\
\hline $1957-1960$ & 84 & 28 & 14 & 21 & 21 & Vinogradov \& Zakutsky (1967) \\
\hline 1991 & 41 & 18 & 12 & 2 & 9 & Mikhailova (2002) \\
\hline $1984-2003$ & 79 & 21 & $25^{*}$ & 21 & 12 & Sinegub (2006) \\
\hline 2012 & 52 & 15 & 14 & 16 & 7 & Kovalishina \& Kachalov (2015) \\
\hline $2010-2013$ & 162 & 39 & 49 & 43 & 31 & Our data \\
\hline
\end{tabular}

Note: * including Oligochaeta and Nemertea.

Table 4. Species richness of benthic macrofauna in different areas of the northwestern Black Sea

\begin{tabular}{|c|c|c|c|c|c|c|c|}
\hline \multirow{2}{*}{ Area } & \multirow{2}{*}{ Period of studies } & \multirow{2}{*}{ Number of stations } & \multirow{2}{*}{ Number of species } & \multicolumn{4}{|c|}{ Relative portion of most diverse taxa } \\
\hline & & & & Mollusca & Polychaeta & Crustacea & Other \\
\hline *Karkinitskiy Gulf & $1973-2003$ & 115 & 166 & 26 & 30 & 31 & 13 \\
\hline *Dnieper - Bug & $1973-2003$ & 2061 & 209 & 24 & 22 & 39 & 15 \\
\hline *Danube - Dniester & 1973-2003 & 674 & 161 & 22 & 24 & 40 & 14 \\
\hline $\mathrm{ZPF}$ & 2010-2013 & 43 & 162 & 24 & 30 & 27 & 19 \\
\hline
\end{tabular}

Note: ${ }^{*}$ - according to Sinegub (2006).
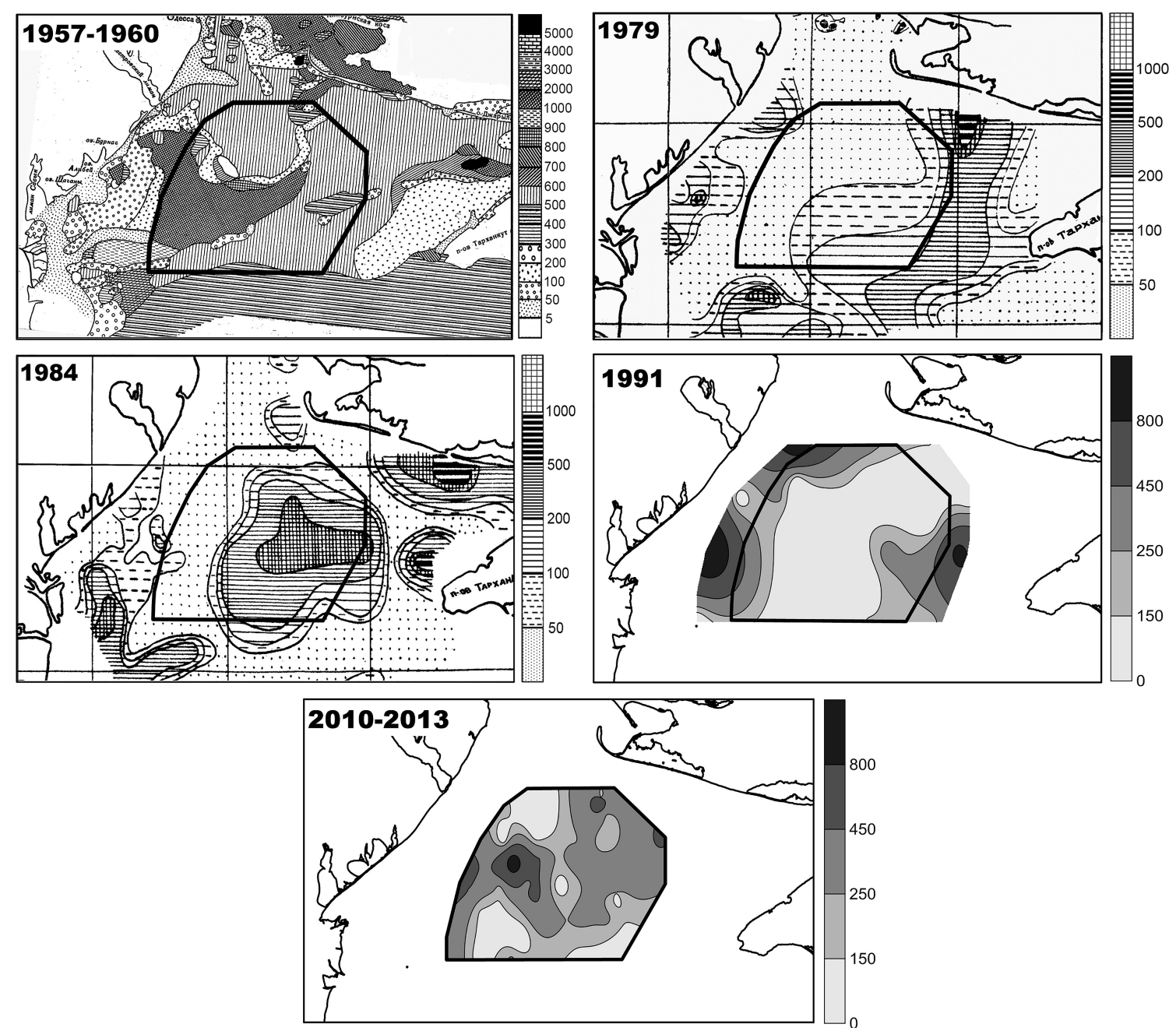

Fig. 4. Spatial distribution maps of the macrozoobenthos biomass $\left(\mathrm{g} / \mathrm{m}^{2}\right)$ in the Zernov's Phyllophora Field area in different years: 1957-1960 (Nikitin, 1964); 1979 and 1984 (Samyshev et al., 1986); 1991, composed according to Mikhailova (2002); 2010-2013 (own data). 
An ecological crisis happened in the Black Sea basin in the second half of the $20^{\text {th }}$ century (its peak occurred at the turn of the 1980s - 1990s (Yunev, 2012), which was mainly associated with the anthropogenic eutrophication and reducing the water column transparency (Zaitsev \& Mamaev, 1997). As a result of these processes a pronounced degradation of the Phyllophora field and a mass mortality of the benthic fauna due to the near-bottom hypoxia appeared (Zaitsev, 2006). The onset of the mass mortality over the extensive near-estuary bottom areas of the NWBS is believed to occur in 1973 (Salsky, 1977). By 1979 , the area with a relatively high level of macrozoobenthos biomass substantially reduced, the mean biomass in the NWBS generally decreased by more than 6 times and amounted to only 135 $\mathrm{g} / \mathrm{m}^{2}$ (Samyshev et al., 1986). Considering to the ZPF area, our calculation (according to data from (Samyshev et al., 1986) shows a 7-fold decrease in the mean macrozoobenthos biomass in 1979 (to $62 \mathrm{~g} / \mathrm{m}^{2}$ ) compared to 1957-1960.

During the period from 1979 to 1989 , a fluctuating in the mean macrozoobenthos biomass with two maxima, in $1981\left(323 \mathrm{~g} / \mathrm{m}^{2}\right)$ and $1986(537 \mathrm{~g} /$ $\mathrm{m}^{2}$ ), was observed in the NWBS (Zolotarev, 1994). In 1984, when there were large zones with a biomass lower than $50 \mathrm{~g} / \mathrm{m}^{2}$ on the NWBS shelf, an intensive development of macrozoobenthos was recorded in the ZPF, where an area with a biomass of $200-500 \mathrm{~g} / \mathrm{m}^{2}$ and more was registered (Samyshev et al., 1986) (Fig. 4). Our prognostic estimates of data reported by Samyshev et al. (1986) show that the mean zoobenthos biomass in the ZPF for that period was $257 \mathrm{~g} / \mathrm{m}^{2}$.

On the map of 1984 (Fig. 4), the central part of the NWBS shelf, including the ZPF, is surrounded by a zone of decreased biomass of macrozoobenthos. The cause of its formation, along with the hypoxia in near-bottom water layers, was the secondary siltation of the bottom substrate as a result of dredge fishing for mussels and bottom trawling (for mainly sprat), which had been conducted in- creasingly in the waters adjacent to the ZPF since the middle of the 1970s. The greatest number of trawl hauls was performed in 1980, and they became regular in the southern sector of the ZPF in the period from 1984 to 1988 (Zolotarev, 1994). According to Samyshev et al. (1986), the total amount of silty fractions of sediments raised to the water column as a result of bottom trawling from 1976 to 1984 reached 60 million tons. Pelitic sediment material was transported over long distances by currents and, according to the scheme presented in the work (Zaitsev \& Mamaev, 1997), embraced the ZPF along the perimeter, coinciding with the ring-shaped zone of decreased macrozoobenthos biomass noted above (Fig. 4). The results of visual surveys of the ZPF using the manned submersible vehicles «Argus» in 1984 (Zaitsev, 2006) and «Benthos» in 1989 (Stroganov \& Gordeeva, 2000) confirmed the intensive process of siltation of the bottom substrate and depletion of the benthic macrofauna due to the anoxia phenomena.

Subsequently, the surge of macrozoobenthos development in the ZPF area was followed by another decline; by 1991, its mean biomass reduced to $158 \mathrm{~g} / \mathrm{m}^{2}$ (Table 5). In 1984, the zone of depressed biomass around the ZPF exactly coincided with the cyclonic trajectory of turbidity currents described by Zaitsev \& Mamaev (1997) and then, from our point of view, by 1991 the centripetal re-sedimentation of suspended matter caused the zone of decreased macrozoobenthos biomass to form already in its central part (Fig. 4). As a result, if earlier (initially) the currents determined formation of the field of unattached Phyllophora in the central part of the NWBS shelf (Zaitsev, 2006), now these same currents, transferring both the secondary fine-fraction suspended matter, stirred up from the bottom by fishing operations, and the excessive detrital component (as the result of eutrophication), jointly determined the zones of minimal development of macrozoobenthos (lower than $100 \mathrm{~g} / \mathrm{m}^{2}$ ) already in the central part of the ZPF (Fig. 4).

Table 5. Estimated quantitative parameters of macrozoobenthos development over the area of $8400 \mathrm{~km}^{2}$ in the Zernov's Phyllophora Field

\begin{tabular}{|l|c|c|c|c|c|}
\hline \multirow{2}{*}{ Parameter } & \multicolumn{5}{c|}{ Year } \\
\cline { 2 - 7 } & $1957-1960$ & 1979 & 1984 & 1991 & $2010-2013$ \\
\hline Total stock of macrozoobenthos, million tons & 3.8 & 0.5 & 2.2 & 1.3 & $3.7(2.4)$ \\
\hline Average biomass of macrozoobenthos, $\mathrm{g} / \mathrm{m}^{2}$ & $458.25^{*}$ & 62 & 257 & 158 & $442(283)$ \\
\hline
\end{tabular}

Note: * based on the data in Vinogradov \& Zakutsky (1967); wet biomass of macrozoobenthos without the mantle cavity fluid of mollusks is indicated in parentheses. 
The excess of organic matter itself is not a cause of macrozoobenthos degradation. Organic matter suspended in the water column is a source of food that determines the level of development of filter-feeders (and particularly mussels) in benthos (Revkov et al., 1999; Petrov, 2000). For example, the increase in values of quantitative parameters of benthos development off the Crimean coast in the Chamelea gallina biocoenosis (Mazlumyan et al., 2004; Revkov et al., 2008; Revkov, 2009, 2011) and in the Mytilus galloprovincialis biocoenosis in Kalamitskiy Gulf (Boltacheva et al., 1999) - occurred due to the increased abundance of filter-feeding mollusks and was recorded immediately at the peak of eutrophication of the Black Sea basin (at the turn of the 1980s - 1990s). The mass expansion of the other bivalve Anadara kagoshimensis, a recent Black Sea invader, is associated with near-estuary waters enriched in organic matter (Revkov, 2016). Thus, the zoobenthos biomass increased in response to water eutrophication off the coast of Crimea. In contrast, the excess of organic matter over the period of summer vertical stratification of waters on the northwestern and western sections of the Black Sea shelf determined the formation of anoxia/hypoxia conditions in the near-bottom horizons. It caused a mass mortality of benthos on large areas while this organics is decomposed (Cociasu et al., 1996; Zaitsev, 2007). Thus, the degradation of benthos with oxygen deficiency and an increase in the parameters of development of filter-feeders can be considered as principal responses of bottom communities regarding to the organic enrichment phenomena of the Black Sea waters. The overall pattern of the observed elimination of macrozoobenthos in the ZPF area in 1979, 1984, and 1991 (Fig. 4) was formed by the combined effect of near-bottom oxygen deficiency and anthropogenic silting of the bottom substrate. In general for the NWBS, the total loss of benthic fauna from 1973 to 1990 is estimated at 55 million tons (Zaitsev, 1992) mainly due to the silting and near-bottom hypoxia/anoxia.

The de-eutrophication of the whole Black Sea basin which started in the middle of the 1990s (Zaika, 2011; Yunev, 2012), the prohibition of bottom trawling for sprats and dredging for mussels introduced in the Ukraine in the late 1980s, and the subsequent strengthening of control of the use of near-bottom fishing gears eventually resulted in the improved general state and parameters of macrozoobenthos development in the ZPF. Undoubtedly, the subsequent recovery and improvement of the ecological state of macrozoobenthos was facilitated by prohibition of brown algae phyllophora production in 1996 and due to establishment in November 2008 the botanical sanctuary of national importance «Zernov's Phyllophora Field» with an area of $4025 \mathrm{~km}^{2}$ (Nature reserves fund of Ukraine, 2009).

According to estimates inferred from maps, in 2010-2013 the average wet biomass of macrozoobenthos in the ZPF amounted $277 \mathrm{~g} / \mathrm{m}^{2}$ (without mantle cavity fluid of bivalve mollusks). This value has actually matched the similar mean values obtained for this period by traditional averaging the biomass values over stations $\left(283.4 \pm 32.3 \mathrm{~g} / \mathrm{m}^{2}\right)$. This fact testifies in favour of the approach that we used in the retrospective analysis of the mapped material.

By results the calculations for 2010-2013 based on biomass of bivalves with mantle cavity fluid, the average macrozoobenthos biomass values increased to $442 \mathrm{~g} / \mathrm{m}^{2}$. The latter value actually agrees with those of the analogous parameters for the pre-crisis period of 1957-1960 (Table 5). Kovalishina \& Kachalov (2015) provided a value of the mean macrozoobenthos biomass in the ZPF for $2012\left(545 \mathrm{~g} / \mathrm{m}^{2}\right)$ that is similar to our own results. This confirms our conclusion about the recovery of the quantitative parameters of macrozoobenthos in the ZPF in 2010-2013 to the level of 1957-1960. A similar conclusion can be drawn about the total stock of macrozoobenthos (Table 5). The results on long-term dynamics of macrozoobenthos biomass in the area of the ZPF coincide with the data obtained for the neighbour areas of the Black sea shelf as Romanian (Cociasu et al., 1996; Begun et al., 2010) and Bulgarian (Todorova \& Konsulova, 2000; Petrova \& Stoykov, 2013) where there is an improvement of the ecological state compared to the recession in the Black Sea ecosystem in the 1980s - 1990s caused by eutrophication and hypoxia phenomena.

\section{Conclusions}

The data obtained in 2010-2013 characterise values of the benthic macrofauna development in the ZPF area in the post-crisis period due to the de-eutrophication of the Black sea basin. The highest level of macrozoobenthos species richness over the entire investigation period of the ZPF has been recorded in these years. Such results can be explained by the more detailed research and, in part, by the wider distribution of invasive species at recent times. As a result of the long-term series of observations, the most critical period for macro- 
zoobenthos of the ZPF was the late 1970s, when its mean biomass and the total stock reduced seven times compared to 1957-1960. The results based on the data collected in the first decades of the $21 \mathrm{st}$ century indicate the actual recovery of the macrozoobenthos biomass in the ZPF to the level observed in the pre-crisis period which can be related to the improving ecological situation in the region.

\section{Acknowledgements}

The authors are deeply grateful to Yu.N. Tokarev for the organisation of expedition works, as well as to G.A. Dobrotinoy for the assistance in sorting out the material and for identification of bryozoans. The study was conducted within the framework of the Russian Academy of Sciences research assignment No. AAAA-A18-118020890074-2.

\section{References}

Akimov I.A. (Ed.). 2009. Red Data Book of Ukraine. Animal world. Kiev: Globalmarketing. 600 p. [In Ukrainian]

Begun T., Теасг A., Gomoiu M.-T. 2010. State of macrobenthos within Modiolus Phaseolinus biocoenosis from Romanian Black Sea continental shelf. Geo-Eco-Marina 16: 5-18. DOI: 10.5281/zenodo.56945

Berenbeim D.Ya. 1953. Giant clusters of red algae on the Black Sea. Priroda 6: 107-108. [In Russian]

Boltacheva N.A., Milchakova N.A., Mironova N.V. 1999. Changes in benthos under the influence of eutrophication in the Kalamitsky Bay area. Ekologia morya 49: 5-9. [In Russian]

Cociasu A., Dorogan L., Humborg C., Popa L. 1996. Longterm ecological changes in Romanian coastal Waters of the Black Sea. Marine Pollution Bulletin 32(1): 32-38. DOI: 10.1016/0025-326X(95)00106-W

Dumont H.J., Mamaev V.O., Zaitsev Y.P. (Eds.). 1999. Black Sea Red Data Book. UNOPS, 1999. 413 p.

Emelianov V.A., Mitropolskiy A.Yu., Nasedkin E.I., Pasynkov A.A., Stepanyak Yu.D., Shnyukova E.E. 2004. Geoecology of the Black Sea shelf of Ukraine. Kiev: Akademperiodika. 295 p. [In Russian]

Gubbay S., Sanders N., Haynes T., Janssen J.A.M., Rodwell J.R., Nieto A., Garcна Criado M., Beal S., Borg J., Kennedy M., Micu D., Otero M., Saunders G., Calix M. 2016. European Red List of Habitats Part 1. Marine habitats. Luxembourg: Publications Office of the European Union. 52 p. DOI: 10.2779/032638

Ivanov S.P., Fateryga A.V. (Eds.). 2015. Red Data Book of the Republic of Crimea. Animals. Simferopol: PP «ARIAL» LLC. 440 p. [In Russian]

Kovalishina S.P., Kachalov O.G. 2015. Macrozoobenthos of Zernov's Phyllophora Field in May - June 2012. Scientific notes of the Ternopil National Pedagogical University. Series Biology 64(3-4): 309-313. [In Russian]

Losovskaya G.V. 2006. Macrozoobenthos. Benthic communities. 1970-1983. In: North-Western part of the Black
Sea: biology and ecology. Kiev: Naukova Dumka. P. 268-276. [In Russian]

Mazlumyan S.A., Boltacheva N.A., Kolesnikova E.A. 2004. Analysis of long-term changes in the diversity of benthos in the bay of Lisya (south-eastern coast of the Crimea). Marine Ecological Journal 3(1): 59-72. [In Russian]

Mikhailova T.V. 2002. Some data on the macrozoobenthos of the Zernov's Phyllophora Field (Black Sea). Ekologia morya 59: 26-30. [In Russian]

Milchakova N. 2011. Marine Plants of the Black Sea. An Illustrated Field Guide. Sevastopol: Digit Print Press. 144 p. DOI: $10.21072 / 978-966-02-5801-3$

Milchakova N.A. 2016. History and prospects for the formation of specially protected area in the Azov-Black Seas basin. In: Proceedings of All-Russian Scientific-Practical Conference with International Participation dedicated to the $145^{\text {th }}$ anniversary of Sevastopol Biological Station. Marine biological research: achievements and perspectives. Vol. 3. P. 45-48. [In Russian]

Nature reserves fund of Ukraine: territories and objects of national importance. Kiev: Centre for Environmental Education and Information, 2009. 332 p. [In Ukrainian]

Nevrova E.L., Snigireva A.A., Petrov A.N., Kovaleva G.V. 2015. Guidelines for quality control of the Black Sea. Microphytobenthos. Sevastopol; Simferopol: N. Orianda. 176 p. [In Russian]

Nikitin V.N. 1964. Quantitative distribution of bottom macrofauna in the Black Sea. Proceedings of the Institute of Oceanology of the USSR Academy of Sciences 69: 285-329. [In Russian]

Petrov A.N. 2000. Reaction of Black Sea coastal macrobenthic communities to organic enrichment of bottom sediments. Ekologia morya 51: 45-51. [In Russian]

Petrova E., Stoykov S. 2013. Biocoenological investigations of the macrozoobenthos in the northern part of the Bulgarian Black Sea coast in depths up to $30 \mathrm{~m}$. Bulgarian Journal of Agricultural Science 19(Suppl. 1): 16-20.

Revkov N.K. 2009. Some remarks on the structure and longterm dynamics of mollusks on soft bottoms at southeast Crimea (the Black Sea). In: Collection of scientific papers dedicated to the 95th anniversary of the Karadag Research Station and 30th anniversary of the Karadag Nature Reserve of the National Academy of Sciences of Ukraine. Sevastopol: EKOSI-Gidrofizika. P. 251-261. [In Russian]

Revkov N.K. 2011. Macrozoobenthos of the Ukrainian zone of the Black Sea shelf. The current state of benthal zoological resources of the Azov-Black Sea basin. In: Biological resources of the Black Sea and Sea of Azov. Sevastopol: EKOSI-Gidrofizika. P. 140-162. [In Russian]

Revkov N.K. 2016. Colonization's features of the Black Sea basin by recent invader Anadara kagoshimensis (Bivalvia: Arcidae). Marine Biological Journal 1(2): 3-17. DOI: 10.21072/mbj.2016.01.2.01 [In Russian]

Revkov N.K., Valovaya N.A., Kolesnikova E.A., Nikolaenko T.V., Shalyapin V.K. 1999. To the state of the Black Sea macrozoobenthos under eutrophication. In: Ecological 
safety of coastal and shelf zones and complex use of shelf resources. Sevastopol. P. 199-212. [In Russian]

Revkov N.K., Abaza V., Dumitrache C., Todorova V., Konsulova T., Mickashavidze E., Varshanidze M., Sezgin M., Ozturk B., Chikina M.V., Kucheruk N.V. 2008. The state of zoobenthos In: T. Oguz (Ed.): State of the Environment of the Black Sea (2001-2006/7). Istanbul, Turkey: Publications of the Commission on the Protection of the Black Sea Against Pollution (BSC) 2008-3. P. 273-320.

Revkov N.K., Boltachova N.A., Bondarev I.P., Timofeev V.A., Bondarenko L.V. 2016. Species richness and quantitative development of macrozoobenthos on Zernov's Phyllophora field. In: A.V. Gaevskaya (Ed.): Marine biological research: achievements and perspectives: Proceedings of All-Russian Scientific-Practical Conference with International Participation dedicated to the $145^{\text {th }}$ anniversary of Sevastopol Biological Station (Sevastopol, 19-24 September, 2016). Sevastopol: EKOSI-Gidrofizika. Vol. 2. P. 126-129. [In Russian]

Salsky V.A. 1977. On mass mortalities of mussels in the north-western Black Sea. Biologiya Morya 43: 33-38. [In Russian]

Samyshev E.Z., Rubinshtein I.G., Zolotarev P.N., Litvinenko N.M. 1986. Variability in the structure of the benthos of the Black Sea under anthropogenic impact. In: Anthropogenic impacts on coastal-marine ecosystems. Moscow: VNIRO Publishing House. P. 52-71. [In Russian]

Shchapova T.F. 1954. Phyllophora of the Black Sea. Proceedings of the Institute of Oceanology 11: 3-35. [In Russian]

Sinegub I.A. 2006. Macrozoobenthos. Benthic communities. 1984-2002 In: North-Western part of the Black Sea: biology and ecology. Kiev: Naukova Dumka. P. 276-286. [In Russian]

Skolka H.V. 1956. Speciile de Phyllophora din apele romanesti ale Marii Negre - raspandirea si importanta lor. Buletinul Institutului de Cercetäri Piscicole 15(4): 84-88.

Stroganov A.A., Gordeeva I.K. 2000. Investigation of the biocenosis of Phyllophora nervosa on the Zernov's Field of Phyllophora via an underwater inhabited vehicle. Ecologia morya 50: 40-44. [In Russian]

Todorova V., Konsulova T. 2000. Long term changes and recent state of Macrozoobenthic communities along the Bulgarian Black Sea coast. Mediterranean Marine Science 1/1: 123-131. DOI: 10.12681/mms.283

Vinogradov K.A. 1957. On the boundaries of Zernov's Phyllophora Field in the northwestern part of the Black Sea. In: Scientific session devoted to the 100th anniversary of the birth of G.I. Tanfilyev. Odessa: Odessa University. P. 69-70. [In Russian]

Vinogradov K.A., Zakutsky V.P. 1967. The phyllophorous field of Zernov. In: Biology of the northwestern part of the Black Sea. Kiev: Naukova Dumka. P. 158-176. [In Russian]

Warwick R.M., Clarke K.R. 2001. Practical measures of marine biodiversity based on relatedness of species. Oceanography and marine biology: an annual review 39: 207-231.

WoRMS Editorial Board. 2018. World Register of Marine Species. Available from http://www.marinespecies.org at VLIZ. Retrieved on 12 May 2018. DOI: 10.14284/170

Yunev O.A. 2012. Anthropogenic eutrophication and its effect on the state of the Black Sea pelagic ecosystem In: Stability and Evolution of the Oceanological Characteristics of the Black Sea Ecosystem. Sevastopol: ECOSY-Hydrophysica. P. 300-330. [In Russian]

Zaika V.E. 2011. De-eutrophication of the Black Sea and the influence of climatic oscillations. In: State of the ecosystem of the shelf zone of the Black and Azov Seas in conditions of anthropogenic impact: a collection of articles dedicated to the 90th anniversary of the Novorossiysk Marine Biological Station named after Professor V.M. Arnoldi. Krasnodar. P. 88-93. [In Russian]

Zaitsev Yu.P. 1992. Ecological state of the shelf zone of the Black Sea off the coast of Ukraine. Hydrobiological Journal 28(4): 3-18. [In Russian]

Zaitsev Yu.P. 2006. Introduction to the ecology of the Black Sea. Odessa: Even. 224 p. [In Russian]

Zaitsev Yu.P. 2007. Recent changes in the trophic structure of the Black Sea. Fisheries Oceanography 1(2): 180 189. DOI: 10.1111/j.1365-2419.1992.tb00036.x

Zaitsev Yu., Mamaev V. 1997. Biological diversity in the Black Sea. A study of change and decline. Vol. 3. NewYork: United Nations Publ. 208 p.

Zakutsky V.P. 1962a. Zoobenthos in the northwestern part of the Black Sea. Odessa: Odessa State University. 17 p. [In Russian]

Zakutsky V.P. 1962b. On the issue of reserves of zoobenthos in the north-western part of the Black Sea. Reports of the Academy of Sciences of Ukrainian SSR 10: 13761377. [In Ukrainian]

Zenkevich LA 1956. The seas of the USSR: their fauna and flora. Moscow: Uchpedgiz. 424 p. [In Russian]

Zernov S.A. 1909. Phyllophora facies (Algae - Rhodophyta) - Phyllophora field in the northwestern part of the Black Sea. Yearbook of the Zoological Museum of the Academy of Sciences (St. Petersburg) 14(3-4): 181191. [In Russian]

Zernov S.A. 1913. On the question of studying the life of the Black Sea. Notes of the Imperial Academy of Sciences. St. Petersburg. Series 8.32(1): 1-299. [In Russian]

Zolotarev P.N. 1994. The structure of the benthic biocenoses of the northwestern part of the Black Sea and its transformation under the influence of anthropogenic factors. PhD Thesis. Kerch. 278 p. [In Russian] 


\title{
МАКРОЗООБЕНТОС ФИЛЛОФОРНОГО ПОЛЯ ЗЕРНОВА (СЕВЕРО-ЗАПАДНАЯ ЧАСТЬ ЧЕРНОГО МОРЯ): ВИДОВОЕ БОГАТСТВО, КОЛИЧЕСТВЕННОЕ РАЗВИТИЕ И МНОГОЛЕТНИЕ ИЗМЕНЕНИЯ
}

\author{
Н. К. Ревков*, Н. А. Болтачева, В. А. Тимофеев, И. П. Бондарев, Л. В. Бондаренко \\ Институт морских биологических исследований имени А.О. Ковалевского РАН, Россия \\ e-mail:*nrevkov@yandex.ru,n.boltachova.15@gmail.com,tamplier74@mail.ru, \\ igor.p.bondarev@gmail.com,bondarenko.luda@gmail.com
}

\begin{abstract}
Филлофорное поле Зернова (ФПЗ) - участок акватории северо-западной части Черного моря (СЗЧМ) в

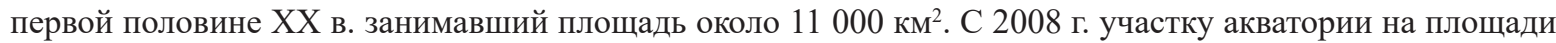

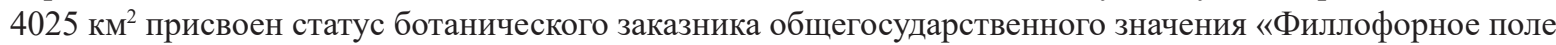
Зернова». Целью работы является оценка, в современных условиях де-эвтрофикациии бассейна Черного моря, видового богатства и количественного развития макрозообентоса ФПЗ и их многолетних изменений. Работа основана на материалах 43-х бентосных станций, выполненных в 2010-2013 гг. на участке ФПЗ площадью 8400 км². В 2010-2013 гг. в составе макрозообентоса обнаружено 162 вида: Polychaeta - 49 видов, Mollusca - 39, Crustacea - 43, Ascidiacea - 6; остальные группы - 25 видов. Современный уровень видового богатства макрозообентоса является наивысшим за весь исторический период иссле-

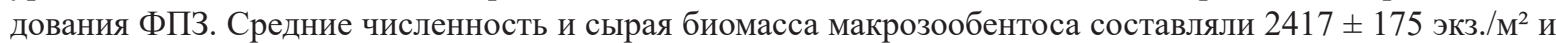
$283.4 \pm 32.3$ г $/ \mathrm{M}^{2}$ (без мантийной жидкости двустворчатых моллюсков); из них Polychaeta $-1017 \pm 128$ экз. $/ \mathrm{M}^{2}$ и $6.4 \pm 0.8$ г $/ \mathrm{M}^{2}$, Mollusca $-887 \pm 102$ экз. $/ \mathrm{M}^{2}$ и $256.3 \pm 30.0$ г $/ \mathrm{M}^{2}$, Crustacea $-165 \pm 20$ экз./ $\mathrm{M}^{2}$ и $1.3 \pm$

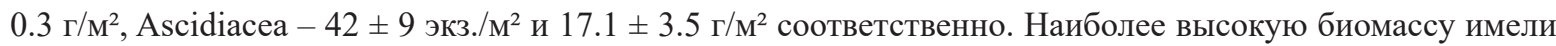
фильтраторы-сестонофаги, среди которых на первом месте Mytilus galloprovincialis (73\% общей сырой биомассы). Наше исследование многолетних изменений донной макрофауны охватывает период $1957-$ 2012 гг., включающий предкризисный этап развития экосистемы Черного моря (1957-1960), его кризис второй половины ХХ в. (1979, 1984, 1991) и современный (посткризисный) этап (2010-2013). На основе карт пространственного распределения биомассы макрозообентоса для всех упомянутых выше периодов

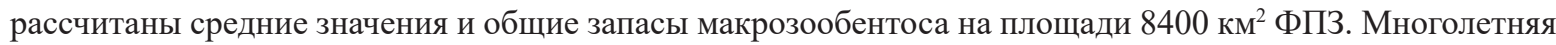
динамика биомассы макрозообентоса анализируется в связи с известными основными факторами воздействия на донные биоценозы NWBS - придонной гипоксией и заморами бентоса из-за эвтрофикации бассейна, и вторичным заилением донного субстрата в результате донного промысла морепродуктов. Результаты анализа указывают, что наиболее кризисным для ФПЗ являлся конец 1970-х гг., когда средняя биомасса и общие запасы макрозообентоса сократились в 7 раз. Данные первого десятилетия XXI в. свидетельствуют о фактическом восстановлении средней биомассы макрозообентоса в районе ФПЗ до уровня 1957-1960 гг., что связано с улучшением экологической ситуации в регионе.
\end{abstract}

Ключевые слова: Phyllophora, биомасса, запасы макрозообентоса, макрофауна бентоса, многолетняя динамика, морская особо охраняемая природная территория, численность 